\title{
Incorporating Blended Learning in an Undergraduate English Course in China
}

\author{
Wei Chen \\ School of English and Education \\ Guangdong University of Foreign Studies \\ Guangzhou, China
}

\begin{abstract}
With the growth of the internet and e-learning, blended learning has become popular, offering various combinations of internal classes and online content. This paper reports the results of delivering a second-year literature course to EFL learners using blended learning. This study demonstrates how blended learning approach is implemented in an EFL environment with the support of Blackboard, a popular learning management system. Data were collected and analyzed from the questionnaire delivered at the end of the semester. The study findings reveal that blended learning offers more flexibility and student support, enhances student engagement thus improving student learning outcomes, and most importantly, increases the interaction between teachers and students.
\end{abstract}

Keywords-blended learning; Blackboard; EFL teaching and learning

\section{INTRODUCTION}

It is clear that we are now at a time where internet and technologies are making an increasingly significant contribution to teaching and learning. This new educational reform and the implementation of information communications technology (ICT) is also a major driving force for teachers to alter their approaches. Blended learning, increasingly adopted by educators and institutions, is one of such approaches. Studies have overwhelmingly shown that blended learning is used to improve pedagogy, increase cost-effectiveness, access and flexibility, and simplify revision [1]. In language learning, especially in the field of English as a foreign language (EFL), the main challenge was for a small number of teachers to help a large number of students to become effective users of English in a non-native context. Blended leaning in language classrooms can motivate and enhance students' language skills [2] this study demonstrates how blended learning approach is implemented in an English literature course with the support of Blackboard, one of the influential learning management system (LMS) in China.

\section{BLENDED LEARNING IN LANGUAGE CLASSROOM}

\section{A. Blended Learning}

Blended learning means different things to different people. Therefore its definitions and understandings of the concept are many. In research literature, the terms "blended learning", "hybrid learning", "technology-mediated instruction", "webenhanced instruction", and "mixed-mode instruction" are often used interchangeably[3] . Graham, Allen, and Ure (2003) [4] documented three definitions: combining instructional modalities or delivery media, combining instructional methods, and combining online and face-to-face instruction. In 2006, the first Handbook of Blended Learning was published by Bonk and Graham. Graham challenged the breadth and ambiguity of the term's definition, and defined "blended learning systems" as learning systems that "combine face-to-face instruction with computer mediated instruction"[5]. These definitions stressed the combination of traditional instructions and online instructions. A definition by Krause (2008) [6] can better explain the significance of this learning mode:

"Blended learning is realized in teaching and learning environments where there is an effective integration of different modes of delivery, models of teaching and styles of learning as a result of adopting a strategic and systematic approach to the use of technology combined with the best features of face to face interaction." (p.2)

From this definition, we can learn that online learning is not just a technological advancement in teaching delivery. An effective integration with face-to-face element is the crucial issue in this learning system.

\section{B. The Reason Why Employ A Blended Learning Approach in Language Classroom}

Blended learning has been implemented with various designs and has shown a considerable positive effect on the learning process. Researchers point out that not all students learn the same way, therefore the traditional approach is not ideal for all students. Accounts in e-learning literature suggest that blended learning has great advantages. It creates opportunities to use new educational tools and increase student engagement. Furthermore, online components offer students with flexible access to course content and instructions at any time and from anywhere with unlimited educational discussion opportunities [7]. In addition, implementing blended learning in some universities was in response to the practical challenges being encountered by faculties and/or in response to student feedback such as poor staff-student contact, large classes and inconsistency in quality and quantity of feedback between markers. [8]

The above accounts are just some advantages researchers found in various courses. For the language classroom, blended learning can make special contributions. First, the online elements of the courses added massively to opportunities for 
far more exposure to, and use of, English than purely face-toface courses could [9]. This blended approach personalized instructor feedback in and outside class. It provides non-face threatening scenarios for all types of students [10], so students feel free and relaxed to use the target language. Second, the main challenge in language classroom was for a small number of teachers to help a large number of students to become effective English users in a very short time. However, the interaction is crucial in language classroom. With such interactive activities online as wiki, discussion board, podcast and so on, it allowed valuable flexibility and interactivity which reinforced classroom learning and empowered learners [11]. Thirdly, the value of face-to-face instruction is also recognized by both students and teachers. With the practice online, students gained their confidence and proved their ability in class. Their "language ego" can be boosted a lot.

This new teaching and learning mode spread to China in 2010s and was quickly utilized in various classrooms at different levels. In EFL environment, studies of blended learning reveal similar results. Students' integrated English competence is improved, along with teachers' teaching and students' learning hours reduced [12]. With an online course as the example, Yang (2017) [13] concluded that the organic connection of on-line and off-line teaching models ensured the quality of English blended teaching.

\section{The Adopted Platform}

There are a lot of tools to construct an online learning environment in blended learning, and the learning management system (LMS) is one of them. A Learning Management System is a web-based soft-ware application that is designed to handle learning content, student interaction, assessment tools and reports of learning progress and student activities. Founded in 1997, Blackboard Learn is a commercially licensed LMS, and is one of the most popular marketable LMSs adopted in higher education institutions. Items as course content, learning modules, assignments, assessment, group wiki, blogs and so on can offer a highly interactive medium for student's personalized learning and teacher's efficient management of the class. In general, the features of an LMS consist of pedagogical factors, learner environment, instructor tools, course and curriculum design, administrator tools, and technical specifications.

\section{DESIGN}

\section{A. Course Introduction}

"Appreciating Literature in English" is a compulsory course for second-year non-English majors in a university of foreign studies in China. The selected readings are arranged in topics. Various texts are included under each topic, such as poetry, short story, chapters from novels and scenes from plays. As to the reasons why using literature in language classroom, Parkinson and Thomas (2016) [14] summarized as follows: cultural enrichment, rhetoric writing, mental training, advanced language study, authentic samples, memorable language, rhythms assimilation, personal experienced, multiple interpretation and convenience. In general, for EFL learners, these literary texts are best language samples for learning the language.

\section{B. Participants}

The study was conducted in five classes, with the total number of students of 180 . Before they are taking this course, all of them have studied other 3 comprehensive language courses in the first year of the university. So their English proficiency ranges from intermediate to advance. However, only one class has experienced online learning with Blackboard as the platform, while the other four have no idea of what it is about.

\section{Procedures}

Before the weekly face-to-face sessions, all relevant documents, such as lecture notes and PowerPoint slides are uploaded to Blackboard. Some videos introducing the author and the background of the literary texts are also given to arouse students' motivation. The instructor archived all reading questions in the discussion boards to collect students' views and questions, which can be further discussed in face-to-face classrooms.

During the face-to-face sessions, students first interpret their understanding of the literary text and work in groups to solve all the puzzles listed in the discussion board. The instructor then works as the facilitator and helper to train their critical thinking as well as prevent students from continually making the same language mistakes. This is in aligning with Sharma \& Barrett's distinction of synchronous and asynchronous communication [15]. It helps to develop fluency of language in synchronous communication while asynchronous communication online helps develop higher order thinking skills since it allows writers to organize their thoughts before posting.

After the face-to-face sessions, assignments as writing, translating and reading (uploading as audio files) can be uploaded to Blackboard. Students are encouraged to keep their blogs online and do some group works via wiki. In the wiki students first draft their writing or translation version, and then make peer comments on each other. At last the draft is revised and a final writing is uploaded to the assignment and assessed by the instructor. The designers of Blackboard suggest that blogs are potentially useful as formative assessment tools because they are reflective and personal in nature. Each student is encouraged to keep their blog as reflection of what they get after reading a certain literary text. Students can do peer reading and comments with rubrics suggested by the instructor. The blog feature also helped track and make visible student participation, which is also tested by Mathews \& Herb (2013)[16] .

\section{RESULTS}

In an attempt to discover the participants' perceptions on the use of Blackboard with the course, a questionnaire was used as an instrument in this study. A five-point Lickert scale was used to rate the responses. For the better understanding of it, the questionnaire was in Chinese. Data obtained from the respondents were calculated using descriptive statistics: percentages and frequencies in "Table. I" 
TABLE I.

Descriptive Statistics on Students' Perceptions In the Questionnaire

\begin{tabular}{|l|c|c|c|c|c|}
\hline & strongly disagree & disagree & neutral & agree & strongly agree \\
\hline It provides an interesting learning style. & $6.88 \%$ & $15 \%$ & $53.13 \%$ & $21.88 \%$ & $3.13 \%$ \\
\hline It helps me a lot in regulating my study. & $4.38 \%$ & $15.63 \%$ & $46.25 \%$ & $28.13 \%$ & $5.63 \%$ \\
\hline It helps me a lot in inproving my English proficiency. & $7.50 \%$ & $16.25 \%$ & $52.50 \%$ & $21.25 \%$ & $2.50 \%$ \\
\hline It encourages me to engage more in classroom activities. & $5.63 \%$ & $11.25 \%$ & $42.50 \%$ & $35 \%$ & $5.63 \%$ \\
\hline It helps me a lot in boosting confidence in learning English. & $8.13 \%$ & $20 \%$ & $47.50 \%$ & $21.88 \%$ & $2.50 \%$ \\
\hline It provides more opportunities to interact with the teacher. & $5 \%$ & $9.38 \%$ & $28.13 \%$ & $47.50 \%$ & $10 \%$ \\
\hline It provides more opportunities to interact with other students. & $6.25 \%$ & $22.50 \%$ & $38.75 \%$ & $28.75 \%$ & $3.75 \%$ \\
\hline It encourages me to share my viers with others in English. & $9.38 \%$ & $20 \%$ & $41.88 \%$ & $25 \%$ & $3.75 \%$ \\
\hline
\end{tabular}

From the data, we can see that over $57.5 \%$ of the respondents agreed that this blended learning approach increased opportunities for interaction with teachers, and over $32.5 \%$ of the respondents strongly agreed it strengthens the interaction with other students. This supports other researchers' findings. Qiu (2014)[17] identified four dimensions of the future classroom interaction: human, technology, resources, and environments. While interpersonal interaction is one of the most common activities. This interaction is to arouse students' interest, exchange ideas, and improve understanding for the knowledge. At the same time, technology is used as a gate-way to the discourse community in education, which allows teachers and learners to bridge the gap between the learning situation and professional contexts by engaging in genuine interaction and collaboration with other learners, teachers, discipline experts, and professionals/students worldwide [18].

Over $40.6 \%$ of the respondents agreed that this approach can encourage them to be more engaged in face-to-face classroom activities. As mentioned by previous studies [19] [20] , students were a source of inspiration; they knew more than we always credited them with and had skills we knew nothing about. Teachers can be learners too and students can help drive the process. In other words, teacher roles are changing, as learners engagement is enhanced by the creation of new learning environments and as they take more decisions in the process.

The next comparatively high percentage comes from the item "Blackboard helps me a lot in regulating my study", and over $33.7 \%$ of the respondents agreed with it. This proves flexibility of blended learning. Some students do not realize that they need more time than their classmate until they get the chance to practice at home. A classroom environment that incorporates blended learning naturally requires learners to demonstrate more autonomy, self-regulation, and independence in order to succeed. [21]

\section{CONCLUSION}

As an innovative approach, with both advantages of online and face-to-face learning, blended learning offers more flexibility and student support, enhances student engagement thus improving student learning outcomes. It is one of the most effective ways for personalized learning at scale. A classroom environment that incorporates blended learning naturally encourages more interaction between instructors, students and learning contexts. It helps to improve the teacher-student relationship and thus facilitates especially the process of teaching and learning a foreign language and makes it more successful.

A learning management system, such as Blackboard, helps develop a better feel for an online community. This virtual learning community integrated with face-to-face instruction are "facilitating student learning, communicating ideas effectively, demonstrating an interest in learning, organizing effectively, showing respect for students, and assessing progress fairly"[22]. On the other hand, the advantages of blended learning are dependent on the quality of the programs being implemented. And also, the technical skill level of students and instructors may be a key challenge to the implementation. The use of blackboard as a blended learning is still focusing on administrative issues rather than pedagogical significance for language learning. Therefore some future studies on that are necessary.

\section{REFERENCES}

[1] Graham, C. R., Allen, S., \& Ure, D. (2005). Benefits and challenges of blended learning environments. In M. Khosrow-Pour (Ed.), Encyclopedia of information science and technology Hershey, PA: Idea Group

[2] Gilbert, Jody (2013). A collaborative online reading and research project. In Whittaker, C., \& Tomlinson, B. (Eds.), Blended learning in English language teaching: Course Design and Implementation. London, UK: British Council.

[3] Martyn ,Margie(2003). The hybrid online model: Good practice. Educause Quarterly: 18-23.

[4] Graham, C. R., Allen, S., \& Ure, D. (2003). Blended learning environments: A review of the research literature. Unpublished manuscript, Provo, UT.

[5] Bonk, C.J. \& Graham, C.R. (2006). The handbook of blended learning environments: Global perspectives, local designs. San Francisco: Jossey - Bass/Pfeiffer. p. 5

[6] Krause, K (2008).Blended learning strategies. Griffith University, Queensland..

[7] Collopy, R. \& Arnold, J. (2009). To blend or not to blend: online and blended learning envi-ronments in undergraduate teacher education. Issues in Teacher Education, 18 (2), 85-101.

[8] Alebaikan, R., \& Troudi, S. (2010). Blended learning in Saudi universities: challenges and perspectives. Alt-J, 18(1), 49 - 59. https://doi.org/10.1080/0968776100365761400

[9] Banados, E (2006) A blended-learning pedagogical model for teaching and learning EFL successfully through an online interactive multimedia environment. CALICO Journal 23/3: 533 - 550.111 
[10] Pardo-Gonzalez, Juanita (2013)Incorporating blended learning in an undergraduate English course in Colombia. In Whittaker, C., \& Tomlinson, B. (Eds.), Blended learning in English language teaching: Course Design and Implementation. London, UK: British Council.

[11] Ingham, Louise (2013). Using a wiki to enhance the learning experience on a business English course. In Whittaker, C., \& Tomlinson, B. (Eds.), Blended learning in English language teaching: Course Design and Implementation. London, UK: British Council.

[12] QI, Hong \& Fu, Zhuqin (2007). Blackboard. An Empirical Study on College English Mixed Teaching Model Supported by Platform. Journal of Xi'an International Studies University. 15(3). DOI: 10.16362/j.cnki.cn61-1457/h.2007.03.024

[13] YANG, Fang, WeI Xing \& ZHANG Wen-xia. (2017) An Exploration of Blended English Teaching Model. Educational technology for foreign language teaching. 2017(2).

[14] 14.Brian Parkinson \& Helen Reid Thomas. 2016. Teaching Literature in a Second Language. Shanghai Foreign Language Education Press.

[15] Leithner, Alison. (2009). Review of Blended Learning: Using Technology In and Beyond the Language Classroom. Language Learning \& Technology, 13(1). 33-39

[16] Mathews, Lanethea \& Herb, Alexandra LaTronica (2013). Using Blackboard to Increase Student Learning and Assessment Outcomes in a Congressional Simulation, Journal of Political Science Education, 9:2, 168-183, DOI: 10.1080/15512169.2013.770986

[17] Feng, Qiu (2014). Study on interactions in classroom of the future. In Cheung, S. K. S., Fong, J., Zhang, J., Kwan, R., \& Kwok, L. F. (2014). Hybrid Learning. Theory and Practice. retrieved from : https://doi.org/10.1007/978-3-319-08961-4

[18] Arnó-Macià, Elisabet. (2012). The Role of Technology in Teaching Languages for Specific Purposes Courses. Modern Language Journal, 96(SUPPL. 1), 89-104. https://doi.org/10.1111/j.15404781.2012.01299.x)

[19] Zhao, Dong-mei \& Yin, Yi (2012). Study on the Teaching Practice of Blackboard-based B-learning Model. Modern Educational Technology, 22(9): 41-43

[20] Aborisade, Peter A (2013). Blended learning in English for Academic Purposes courses: A Nigerian case study. In Whittaker, C., \& Tomlinson, B. (Eds.). (2013). Blended learning in English language teaching: Course Design and Implementation. London, UK: British Council.

[21] McGee, Patricia \& Reis, Abby. (2012) Blended course design: A synthesis of best practices. Journal of Asynchronous Learning Networks. 16(4)

[22] Hartman, J., Moskal, P., \& Dziuban, C. (2005). Preparing the academy of today for the learner of tomorrow. In D. G. Oblinger \& J. L. Oblinger (Eds.), Educating the Net Generation, 6.1-6.15. Retrieved from http://www.educause.edu/educatingthenetgen/ 